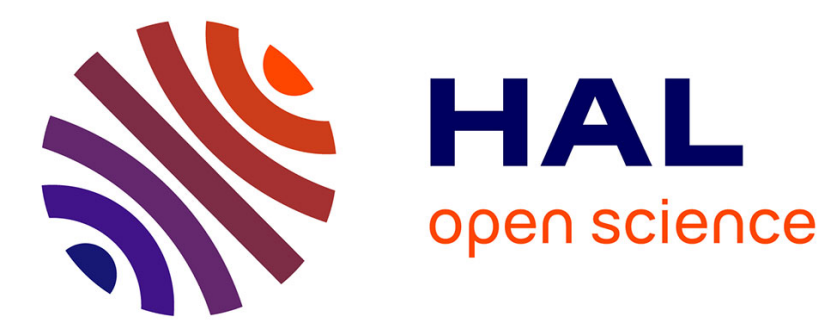

\title{
About the transparent electrode of the organic photovoltaic cells
}

J.-C. Bernède, D.-T. Nguyen, Linda Cattin, M. Morsli, S.R.B. Kanth, S. Patil

\section{To cite this version:}

J.-C. Bernède, D.-T. Nguyen, Linda Cattin, M. Morsli, S.R.B. Kanth, et al.. About the transparent electrode of the organic photovoltaic cells. European Physical Journal: Applied Physics, 2011, 56 (3), pp.34102. 10.1051/epjap/2011110120 . hal-00756412

\section{HAL Id: hal-00756412 \\ https://hal.science/hal-00756412}

Submitted on 23 Nov 2012

HAL is a multi-disciplinary open access archive for the deposit and dissemination of scientific research documents, whether they are published or not. The documents may come from teaching and research institutions in France or abroad, or from public or private research centers.
L'archive ouverte pluridisciplinaire HAL, est destinée au dépôt et à la diffusion de documents scientifiques de niveau recherche, publiés ou non, émanant des établissements d'enseignement et de recherche français ou étrangers, des laboratoires publics ou privés. 


\title{
About the transparent electrode of the organic photovoltaic cells
}

\author{
J.C. Bernède ${ }^{a}$, D-T. Nguyen ${ }^{b}$, L. Cattin $^{\mathrm{b}}$, M. Morsli ${ }^{\mathrm{c}}$, S. R. B. Kanth ${ }^{\mathrm{d}}$, S. Patil $^{\mathrm{d}}$. \\ ${ }^{a}$ UNAM, Moltech Anjou, UMR 6200, 2 rue de la Houssinière, BP 92208, Nantes, F-44000 \\ France. \\ ${ }^{b}$ UNAM, Institut Jean Rouxel (IMN), UMR 6502, 2 rue de la Houssinière, BP 92208, Nantes, \\ F-44000 France. \\ ${ }^{c}$ UNAM, LAMP, EA 3825, Faculté des Sciences et des Techniques, 2 rue de la Houssinière, \\ BP 92208, Nantes, F-44000 France. \\ ${ }^{d}$ Solid State and Structural Chemistry Unit, Indian Institute of Science, Bangalore -560012, \\ India.
}

\begin{abstract}
Electrodes and the nature of their contact with organic materials play a crucial role in the realization of efficient optoelectronic components. Whether the injection (organic light emittin g diodesOLEDs) or collection (organic photovoltaic cells -OPV cells) of carriers, contacts must be as efficient as possible. To do this, it is customary to refer to electrode surface treatment and / or using a buffer layer all things to optimize the contact. Efficiency of organic photovoltaic cells based on organic electron donor/organic electron acceptor junctions can be strongly improved when the transparent conductive anode is coated with a buffer layer (ABL). We show that an ultra-thin gold $(0.5 \mathrm{~nm})$ or a thin molybdenum oxide (3-5 nm) can be used as efficient ABL. However, the effects of these ABL depend on the highest occupied molecular orbital (HOMO) of different electron donors of the OPV cells. The results indicate that, in the case of metal ABL, a good matching between the work function of the anode and the highest occupied molecular orbital of the donor material is the major factor limiting the hole transfer efficiency. Indeed, gold is efficient as ABL only when the HOMO of the organic donor is clos e to its work function $\Phi_{\mathrm{Au}} \cdot \mathrm{MoO}_{3}$ has a wider field of application as ABL than gold, The role of the oxide is not so clearly understand than that of $\mathrm{Au}$, different models proposed to interpret the experimental results are discussed.
\end{abstract}

PACS. 68.35-p, 73.30.+y, 73.40.Qv, 81.10.Pq.

\section{Introduction}

During the last decade, semiconducting organic materials and devices based on them have become one of the main fields of investigation in the optoelectronic domain. For instance, organic photovoltaic cells (OPV) are now reaching power conv ersion efficiency (PCE) around $8 \%$, which gives reasonable prospect for large -area, inexpensive and efficient energy conversion in the near future. The earth of the organic solar cells consists either of two organic layers or a homogeneous mixture of two or ganic materials. One of them - either an organic dye or a semiconducting polymer - is the electrons donor (ED). The other component serves as the electron acceptor (EA).If promising results have been achieved using bulk heterojunction photovoltaic cells [1], interesting results have also been obtained using double heterostructure photovoltaic cells [2]. Although impressive progresses have been done during last years, the OPV cells efficiency is still in need of improvement. Organic semiconductors are quite different in nature relative to inorganic semiconductors. Thus, the chemistry and physics of organic thin films is different from that of inorganic materials. In organic semiconductors, molecular and polymer, the charge carriers are localized on molecules since there is no strong intermolecular bonding and therefore there is no strong inter-atomic bonds and overlap of atomic wave functions. Therefore there are no dangling bonds with deep electronic traps and optical recombination centres. Such unique qualit y of organic materials 
opens new possibilities for device architecture and fabrication techniques. If organic films are deposited without any constraint of lattice match, which usually limits the fabrication of inorganic devices, a general problem in organ ic electrical devices is the transport of charge carriers at the interfaces electrode/organic material. Interfacial phenomena represent a challenge and important area in organic devices science and technology. A variety of interfacial treatments have been applied to interfaces, different more or less thin buffer layers have been placed at these interfaces, resulting in varying degrees of devices improvement in term of charge exchange [3].

For example, several attempts to improve the interface anode/electro $\mathrm{n}$ donor have been done. The experience has shown that the surface chemistry of the transparent conductive oxides (TCO) is not so easy to control [4]. Indeed, it has been shown that the reproducibility of the results obtained, when pristine ITO is used as anode, is in need of improvement. High and reproducible work functions are difficult to obtain for ITO [5]. Often, a thin layer of poly(ethylene dioxythiophene doped with polystyrene sulfonic acid (PEDOT:PSS), which is a conductive polymer, is deposited by spin coating onto the ITO film before organic deposition. This buffer layer is very efficient since it allows achieving good adjustment of the work function, passivation of surface defects and it smoothes the ITO surface. However, PEDOT:PSS is problematic since it degrades under UV illumination, it introduces water into the active layer and it is slightly acidic [6]. Oxidation of ITO surface by $\mathrm{O}_{2}$ plasma or UV ozone treatment can increase its work function, $\Phi_{\text {Iто, }}$ up to nearly $=5 \mathrm{eV}$ [7]. However, the energy value of the highest occupied molecular orbital (HOMO) of the majority of the organic electron donors is larger than $5 \mathrm{eV}$ and the interface band matching is still poor. Therefore a lot of works have been dedicated at the improvement of the inte rface organic acceptor/cathode.

The introduction of a thin anode buffer layer (ABL) between the ITO and the ED induces a significant improvement of the device efficiency [ 8]. For instance, we have shown that Au [9] and $\mathrm{MoO}_{\mathrm{x}}$ [10] allow achieving this goal, by simple vacuum deposition of an ultra-thin gold film or of a thin $\mathrm{MoO}_{\mathrm{x}}$ film when CuPc is the ED. Here, the effects of a gold or $\mathrm{MoO}_{\mathrm{x}} \mathrm{ABL}$ onto the ITO anode are studied using ED with different HOMO. The results indicate that a good matching between the work function of the anode and the HOMO of the organic electron donor is the most important factor limiting the hole transfer efficiency. It is shown that if the $\mathrm{MoO}_{\mathrm{x}}$ oxide has a wider field of application as ABL than the Au metal .

\section{Experimental}

The ITO coated glass substrates were obtained from the SOLEMS. The standard substrate dimensions were $25 \mathrm{~mm}$ by $20 \mathrm{~mm}$. Since ITO covered the whole glass substrates, some ITO must be removed. After masking a broad band of $20 \mathrm{~mm}$ by $20 \mathrm{~mm}$, the ITO was etched by using $\mathrm{Zn}+\mathrm{HCl}[11]$.

After scrubbing with soap and rinsing in running deionised water, the substrates were dried with an argon flow and then loaded into a vacuum chamber $\left(10^{-4} \mathrm{~Pa}\right)$. T he ITO square resistance was about $15 \Omega$. . [12].

In the present study, we focus on the contact between the anode and the electron donor (ED). We have used OPV cells with double heterostructure photovoltaic configuration. It is known that, in such structures, a buffer layer, between the electron acceptor and the cathode increases strongly the cells performances. This interlayer is called "exciton blocking layer" (EBL). Bathocuproine (BCP) is a widely used performing EBL [13] and it has been chosen in the present work. The cathode is a thin aluminium film.

Fullerene, which is the most often used electron acceptor (EA), has been used in the present work. To study the influence of the HOMO (Highest Occupied Molecular Orbital) value of the organic 
material on the effectiveness of the anode buffer laye $\mathrm{r}$ (ABL) different ED have been probed: pentacene, copper phthalocyanine (CuPc), tetraphenyldibenzoperiflanthene (DBP), terthiophene-pyran-malonitrile (T3PM) with $5 \mathrm{eV}, 5.2 \mathrm{eV}, 5.5 \mathrm{eV}$ and 5.7 as HOMO value respectively (Scheme 1). The choice of the different donor materials is related to their HOMO values. By choosing the four ED enumerated above we choose two ED with an HOMO around $5 \mathrm{eV}$ and two around $5.5 \mathrm{eV}$. Therefore we have two families with sufficiently high HOMO difference to clearly see the impact of the HOMO on the effectiveness of the buffer layer and the presence of two compounds in both families allows us to give more reliable interpretation of the results.

In this work, the effects of a gold or $\mathrm{MoO}_{\mathrm{x}} \mathrm{ABL}$ onto the ITO anode are probed using ED with different $\mathrm{HOMO}$. Therefore typical OPV structures probed were glass $/ \mathrm{ITO} / \mathrm{ABL} / \mathrm{ED} / \mathrm{C}_{60} / \mathrm{BCP} / \mathrm{Al}$. All the films were deposited under vacuum at a pressure of $10^{-4} \mathrm{~Pa}$. The thicknesses were $40 \mathrm{~nm}, 9 \mathrm{~nm}$ and $130 \mathrm{~nm}$ for $\mathrm{C}_{60}, \mathrm{BCP}$ and $\mathrm{Al}$ respectively. The ABL thicknesses were $0.5 \mathrm{~nm}$ [9] and $3.5 \mathrm{~nm}$ [10] for $\mathrm{Au}$ and $\mathrm{MoO}_{3}$ respectively. The thickness of the different ED layers have been optimized, they are $35 \mathrm{~nm}$ for CuPc, $25 \mathrm{~nm}$ for pentacene, $20 \mathrm{~nm}$ for DBP and T3PM. The thicknesses and the deposition rates of the layers were monitored by quartz. All the thicknesses are announced further to a calibration of the values measured by the quartz monitor, and by the SEM visualization of the cross section of the films. The deposition rate of the organic material was $0.05 \mathrm{~nm} / \mathrm{s}$. The acti ve area of the devices was $0.2 \mathrm{~cm}^{2}$. All the chemical products have been provid ed by Aldrich except for T3PM synthesized in the laboratories of SSSCU-IIS of Bengalore (India) and DBP provided by LUMTEC. They were used without any purification. Indeed, it ha s been shown that, using the same charge in the evaporation crucible, there is an "auto purification" of the product [ 14]. It should be noted that in the case of T3PM, the HOMO and LUMO values given in table 1 have been estimated by cyclic voltammetry by the Indian team.

The surface topography of the films was observed with field emission scanning electron microscopes (SEM, JEOL F-6400 - 7600).

Electrical characterizations were performed with an automated I -V tester, in the dark and under sun global AM 1.5 simulated solar illumination. Performances of photovoltaic cells were measured using a calibrated solar simulator (Oriel $300 \mathrm{~W}$ ) at $100 \mathrm{~mW} / \mathrm{cm}^{2}$ light intensity adjusted with a PV reference cell $\left(0.5 \mathrm{~cm}^{2}\right.$ CIGS solar cell, calibrated at NREL, USA). Measurements were performed at an ambient atmosphere. All devices were illuminated through TCO electrodes [15].

\section{Experimental results}

For each cells family at least 10 cells have been probed and similar results have been obtained.

\subsection{Without buffer layer}

Here the typical OPV cell was: glass/ITO/ED/C 60 /BCP/Al. As discussed above, different techniques, such as different surface treatments, can be used to improve the ITO work function. However, the objective of the present work was to study the efficiency of various buffer layers in front of the use of donors of different properties. Therefore we used ITO substrates after only soaping and rinsing. Typical current density-voltage (J-V) characteristics of the OPV cells with $\mathrm{CuPc}$, pentacene and DBP as ED are shown in Fig.1. It can be seen that the shape of the curves present a kink effect, which induces a small fill factor (FF). Indeed, we have the following values of the short circuit current (Jsc) : 2.32, 4.67 and $0.11 \mathrm{~mA} / \mathrm{cm}^{2}$, the open circuit voltage (Voc) : $0.29,0.44$ and $0.27 \mathrm{~V}$, the fill factor (FF) : 24, 
38 and $22 \%$, the efficiency : $0.16,0.81$ and $0.03 \%$ for pentacene, CuPc and DBP respectively. Worst results are obtained with T3PM, since the values of Jsc, Voc, FF and PCE are $0.36 \mathrm{~mA} / \mathrm{cm}^{2}, 0.02 \mathrm{~V}, 25 \%$ and $0.002 \%$ respectively. Globally, the power conversion efficiency (PCE) of these cells is not good, and will be discussed below .

\subsection{Au buffer layer}

Here, a typical cell was: glass/ITO/Au/ED/C ${ }_{60} / \mathrm{BCP} / \mathrm{Al}$. The results achieved are summarized in figure 2. It can be seen that far better results are achieved with penta cene and $\mathrm{CuPc}$ in the presence of the ultra-thin gold buffer layer. The Jsc are $6.26,7.07$ and $0.36 \mathrm{~mA} / \mathrm{cm}^{2}$, Voc are $0.35 ; 0.49$ and $0.29 \mathrm{~V}, \mathrm{FF}$ are 47,54 and $24 \%$ and the PCE are 1.02, 1.90, $0.13 \%$ for pentacene, CuPc and DBP respectively, while in the case of T3PM we have Jsc $=0.92$, Voc $=$ $0.07, \mathrm{FF}=30$ and $\mathrm{PCE}=0.02$. In the presence of the gold buffer layer, the strong increase of FF and Jsc, in the case of pentacene and CuPc allows achieving far higher eff iciencies. In the case of DBP and T3PM, if there is some improvement of the cells performances, the efficiencies achieved stay very small and another buffer layer should be probed.

The modification of the morphological and optical properties of the ITO films after deposition of $0.5 \mathrm{~nm}$ of Au has been studied by atomic force microscopy (AFM) and spectrometry (Carry spectrometer). The light transmission was measured at wavelengths of 2 to $0.25 \mu \mathrm{m}$.

The ITO surface roughness is not modified by Au deposition. While the measured ITO roughness $(\mathrm{rms})$ is $0.80 \mathrm{~nm}$, after Au deposition it is $0.76 \mathrm{~nm}$. The fact that the roughness of the ITO electrode is higher than the thickness of the metal film suggests that metal might not form a continuous film, which has been put directly in evidence by the SEM micrograph [9]. Therefore, the thickness given by the quartz monitor is only an averaged thickness. About the optical transmission, for $0.5 \mathrm{~nm}$ thick gold film the transmittance decrease is only $0.5 \%$ between $350 \mathrm{~nm}$ and $1100 \mathrm{~nm}$.

\section{3 $\mathrm{MoO}_{\mathrm{x}}$ buffer layer}

The typical cell was: glass $/ \mathrm{ITO} / \mathrm{MoO}_{3} / \mathrm{ED} / \mathrm{C}_{60} / \mathrm{BCP} / \mathrm{Al}$. The results are presented in figure 3 . It can be seen that the shape of all the curves are exempt of any kink ef fect. Here, the Jsc are 6.59, 7.50, 3.01 and 3.26, the Voc are 0.33, 0.47, 0.76 and 0.30, the FF are 45, 54, 38 and $35 \%$ and the PCE are $0.95,1.90,0.88$ and $0.34 \%$ for pentacene, CuPc, DBP and T3PM respectively. In the case of pentacene and $\mathrm{CuPc}$, the result s are similar to those obtained with a gold buffer layer. For DBP and T3PM Jsc and FF are strongly improved witch induces a significant PCE improvement. However it can be seen that while the Voc of DBP passes from $0.30 \mathrm{~V}$ to $0.76 \mathrm{~V}$, that of T3PM does not ov ertake $0.3 \mathrm{~V}$. Such small Voc is unexpected for an ED with large HOMO, since it is admitted that Voc increases with the difference between the HOMO of the ED and the LUMO of the EA. Indeed, lowering of Voc values can arise from pin-holes, which short-circuit the PV cell, also bad interface band matching at the contact electrode/organic material can decrease the Voc value. As it will be discussed below, the use of $\mathrm{MoO}_{3}$ buffer layer permits improving the band matching at the interface ITO/ED, therefore it is likely that the small Voc value of the OPV cells using T3PM as Ed is related to some leakage current induced by interface inhomogeneities. So, we have checked the homogeneity of the organic layer deposited onto $\mathrm{MoO}_{3}$ /ITO anodes by surface visualisation (Figu re 4a). For comparison, we present in Figure $4 \mathrm{~b}$ the surface visualization of DBP thin film deposited onto $\mathrm{MoO}_{3} / \mathrm{ITO}$, which gives a high Voc value solar cell (Figure3). It can be seen that, while the DBP surface is highly homogeneous, that of T3PM is not. I ndeed, zones of shape round, more or less dark are irregularly distributed in the matrix of the film. Such inhomogeneities can correspond to thickness variations of the organ ic films with possible pinholes, which can 
be at the origin of the leakage current and therefore the small Voc value of OPV cells using DBP.

Here also, the modification of the morphological and optical properties of the ITO films after deposition of $3.5 \mathrm{~nm}$ of $\mathrm{MoO}_{3}$ has been studied by atomic force microscopy (AFM) and spectrometry (Carry spectrometer). The light transmission was measured at wavelengths of 2 to $0.25 \mu \mathrm{m}$.

The ITO surface roughness is not significantly modified by the $\mathrm{MoO}_{3}$ deposition, since the rms increase measured is only $0.1 \mathrm{~nm}$, which is situated in the domain of the exp erimental error.

About the optical transmission, the presence of $3.5 \mathrm{~nm}$ of $\mathrm{MoO}_{3}$ does not induce any significant modification of the ITO transmittance between $350 \mathrm{~nm}$ and $1100 \mathrm{~nm}$.

\section{Discussion}

We have seen in the experimental chapter that, while Au buffer layer is very efficient in the case of pentacene and CuPc it is not for DBP and T3PM On the contrary, $\mathrm{MoO}_{\mathrm{x}}$ is efficient for all the ED probed. As shown by the experimental study; these different behaviours cannot be explained by the modification of the optical or morphological properties of the ITO film by the ABLs $\left(\mathrm{Au}\right.$ or $\left.\mathrm{MoO}_{3}\right)$. It cannot be either explained by the influence of $\mathrm{ABL}$ material on the roughness of the ED film since, in the case of $\mathrm{CuPc}$ for instance, above Au the rms of the $\mathrm{CuPc}$ film is $1.0 \mathrm{~nm}$, while it is $0.9 \mathrm{~nm}$ above $\mathrm{MoO}_{3}$. Here also, such small difference is situated in the domain of the experimental error. As shown in table I, the EDs differ essentially by their HOMO levels. It is known that after simple soap-water cleaning, the work function value of the ITO anode is about $\Phi_{\text {Іто }}=4.4 \mathrm{eV}[16,17]$ to $4.8 \mathrm{eV}[18,19]$. This

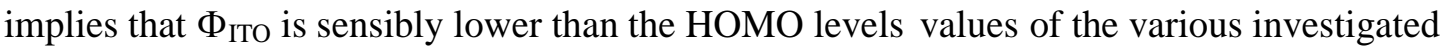
EDs that are all $\geq 5.0 \mathrm{eV}$. The difference between the work function $\left(\Phi_{\mathrm{M}}\right)$ of the anode and the HOMO of the ED has strong influence on the flat band conditions of optoelectronic devices [20,21].

In the light of inorganic semiconductor/metal interfaces, the simple Schottky-Mott model has been often applied to organic contacts. When an o rganic semiconductor is put in to contact with an electrode, the Schottky-Mott model assumes an alignment of the Fermi levels The barrier is then equal to the energy difference between the work function $\left(\Phi_{\mathrm{M}}\right)$ of the anode and the HOMO of the ED.

The Schottky-Mott model is an ideal and simple model. However, real energy level alignment should often consider a vacuum level discontinuity associated with an interface dipole, $\Delta$, resulting from charge rearrangeme nt upon interface formation [22].

In the case of inorganic metal/semiconductor contacts, to take into account the interface states, Bardeen proposed a model, where a large density of surface states induces a pining effect of the Fermi level and the presence at the interface of a barrier independent of the metal work function.

The Cowley-Sze model is an intermediate model, where interface states would be induced in the original band gap of the semiconductor upon contact with a metal giving the interfacial dipole $\Delta$. The effective barrier height for hole exchange $\Phi_{\mathrm{b}, \text { eff }}$ is therefore given by :

$$
\Phi_{\mathrm{B}, \mathrm{eff}}=\Phi_{\mathrm{B}-\Delta}=\Phi_{\mathrm{M}}-\mathrm{HOMO}-\Delta
$$

The sign of $\Delta$ depends on the nature of the contact.

In the case of organic/metal interface, even if the effect of the energy difference between the work function $\left(\Phi_{\mathrm{M}}\right)$ of the anode and the HOMO of the ED on the electrical characteristics of 
the devices is often modulated by a dipole $(\Delta)$ formation at the interface, it is admitted that this difference provides a hole collection barrier in OPV cells [23].

It has been already shown that the presence of such a barrier induces the presence of the kink effect in the J-V characteristics (Figure 1) [24]. These barriers decrease Jsc, FF and therefore the PCE of OPVs. This barrier effect can be minimized through the introduction of a buffer layer.

In the present work we have used different $A B L$ to increase the anode work function. The experimental results let appear that the work function of the gold ABL is a key parameter to adjust the work function of the anode to the HOMO of the organic material. The work function of soaped rinsed ITO is around $4.6 \pm 0.2 \mathrm{eV}$, which is much lower than the HOMO level of the EDs used in the present work. Therefore the energy conversion efficiency of the $\mathrm{OPC}$, whatever the $\mathrm{ED}$, is very poor.

The Au work function, $\Phi_{\mathrm{Au}}$, is $5.2 \mathrm{eV}$ and good efficiencies are achieved with pentacene and $\mathrm{CuPc}$, which HOMO levels are 5.0 and $5.2 \mathrm{eV}$ respectively. On the contrary very low efficiencies are achieved when the ED is DBP and T3PM, because their HOMO levels, 5.5 and $5.7 \mathrm{eV}$ respectively, are far higher than $\Phi_{\mathrm{Au}}$. Therefore it appears clearly that Au is not a universal ABL, since a good matching between the ABL metal work function and the HOMO of the ED is necessary.

The present study has shown that the $\mathrm{MoO}_{3}$ is efficient for a broader domain of HOMO values. Other transition metal oxide $\left(\mathrm{WO}_{3}, \mathrm{~V}_{2} \mathrm{O}_{5}, \mathrm{NiO}\right)$ have been probed as efficient ABL. Although such interface improvement has been often carried out [8, 23-26], the operation mechanism of these $\mathrm{ABL}$ is still in debate. The typical values which characterize the properties of the $\mathrm{MoO}_{3}$ are: The work function, $\Phi_{\mathrm{MoO} 3}$, the top of the valence band, VB, which is the ionisation potential, IP, the bottom of the conduction band, BC, which is the electronic affinity (EA). Moreover, following the deposition technique used, the measurement conditions and techniques, broad discrepancy on the values of these constants exists, as show $\mathrm{n}$ in the table 2. While the usual values admitted for the EA and IP of $\mathrm{MoO}_{3}$ are 2.3 et $5.3 \mathrm{eV}$ respectively, new studies have proposed far higher values: 6.7 and $9.7 \mathrm{eV}$ with a $\Phi_{\mathrm{MoO} 3}$ value of $6.86 \mathrm{eV}$, the films being "strongly" $\mathrm{n}$-type [27]. Moreover, it can be seen in the table 2 that $\Phi_{\mathrm{MoO} 3}$ depends on the surface contamination, or not, of the film, on its composition. It is well known that after deposition by thermal evaporation the films are $\mathrm{MoO}_{3-\mathrm{x}}$ films, with a composition gradient along the film thickness. It is also known that, the oxygen deficienc y increases the film conductivity, while $\mathrm{MoO}_{2}$ is metallic-like. Following the measured physical values for the $\mathrm{MoO}_{3}$, different models have been proposed to explain the improvement effect induced by the $\mathrm{MoO}_{3} \mathrm{ABL}$. The most proposed, supposes that the values are the ones mostly suggested knowing 2.3 and $5.3 \mathrm{eV}$ for EA and IP respectively. It is suggested that such IP corresponds to the HOMO of the ED, which facilitates a good band matching and easy hole s collection, while the $\mathrm{MoO}_{3}$ film behaves as an electron blocking layers [28]. However, we have seen that gold is only efficient when $\Phi_{\mathrm{ABL}}$ is nearly equal to the HOMO of the donor, which is not really the case for $\mathrm{MoO}_{3}$ in the case of the ED with high value probed in the present study. It has been deduced from an XPS study that some electrons transfer from the ITO to $\mathrm{MoO}_{3}$. Such charge transfer could induce a good matching between the Fermi levels of $\mathrm{MoO}_{3}$ and ITO, resulting in the formation of an ohmic contact [29]. Moreover, some dipole effect, induced by charge transfer, could be present at the interface anode/organic material. The evidence of a charge transfer between $\alpha$-NPD (N-N'-diphenyl-N-N'-bis(1-naphthyl)-1, 1'-biphenyl-4,4'-diamine) and $\mathrm{MoO}_{3}$ has been proved through the apparition of a broad absorption peak, around $1350 \mathrm{~nm}$, in the absorption spectra of a $\mathrm{MoO}_{3}: \alpha-\mathrm{NPD}$ composite film [30] .

Having measured far larger IP ( $9.66 \mathrm{eV})$ and EA $(6.21 \mathrm{eV})$ values, Kröger et col. [27], who discuss the same contact $\alpha$-NPD/ITO, propose a different model. Indeed if IP is $9.66 \mathrm{eV}$, it 
should be very difficult for a hole to transit through the $\mathrm{MoO}_{3}$ valence band, as depicted in several publications, since the barrier for electrons from the $\alpha$-NPD to the $\mathrm{MoO}_{3}$ conduction band is only $0.6 \mathrm{eV}$, while the $\mathrm{MoO}_{3}$ valence band is nearly $3 \mathrm{eV}$ below $\Phi_{\text {Iто. These values }}$ are deduced from UPS measurements, which show the presence of large dipole values at the contacts with $\mathrm{MoO}_{3}$. Therefore they propose that the holes exchange between the organic material and the ITO, results from electrons exchange between the HOMO of $\alpha$-NPD and the ITO, through the $\mathrm{MoO}_{3}$ valence band.

In another manuscript [31] the same group has studied by UPS the influence of ambient contamination on the surface properties of $\mathrm{MoO}_{3}$, they show that IP, EA and $\Phi_{\mathrm{MoO} 3}$ have decreased of more than $1 \mathrm{eV}$. However, they also show that the hole transfer is not modified, the dipole value at the interface $\mathrm{MoO}_{3} / \alpha$-NPD having also decreased of the same value.

On the contrary, Zhang et col. [32] show that the contamination of the surface of $\mathrm{MoO}_{3}$, not only decreases IP, EA and $\Phi_{\mathrm{MoO} 3}$, but also its efficiency as buffer layer in OPV cells plug.

Others hole paths have been proposed introducing gap states in the $\mathrm{MoO}_{3}$ [33]. Indeed as said above the evaporated films are not stoichiometrics but oxygen deficient, which can induce band gap state formation.

Of course, the band matching of the interfaces electrodes/or ganic material is not the only limiting factor of OPV performances. For instance, recently, different works have been devoted to the influence of recombination mechanisms, related to the disorder present in the organic material, on the Voc value [38-40]. Such phenomena should not be excluded. However all these works are devoted to bulk heterojunctions and the disorder in a blend is higher than that present in superposed layers of molecules. Therefore, if present, such phenomena do not exclude another well known limiting factor: the interface band matching discussed in the present work.

\section{Conclusion}

As a conclusion, in the case of bare and metal $(\mathrm{Au})$ covered ITO, we have shown that, even if dipole effect is often present at the interface due to interface s tates, a first approach can be done using the Schottky-Mott model. A good correlation exists between the "metal/buffer layer" work function and the barrier $\Phi_{\mathrm{b}}$ for hole exchange at anode/organic electron donor interfaces. In the case metal transition oxide $\left(\mathrm{MoO}_{3}\right)$, we have shown that the $\mathrm{MoO}_{3}$ is efficient for a broader domain of HOMO values. However as shown in the discussion, the role of the oxide is not so clearly understand. The amplitude of the dispersal of the results concerning the values of IP, EA and $\Phi_{\mathrm{MoO} 3}$ justifies that several models are proposed to interpret the experimental results. It is likely that the contradictory results of the diverse teams are due to the different experimental conditions used for these studies, as well as regards the conditions of depositions as those of measures. Nevertheless, whatever the properties of the used product, whether it is deposited by evaporation under ultra high or classical secondary vacuum, by using a Knudsen cell or a simple metallic crucible, by electrochemistry or, by solgel process, whether it is more or less oxygen deficient, it is always effective as buffer layer. It means probably that, if its IP, EA and $\Phi_{\mathrm{MoO} 3}$, are of importance others properties are also determining for its use as buffer layer. Doubtless its volume properties, its homogeneity were too little studied this day, also as regards the influence of the deficiency in oxygen. Of this fact we lead at the same time an experimental study of these properties and a theoretical study of the influence of the oxygen vacancies.

\section{References}

1. W. Cai, X. Gong, Y.Cao, Sol. Energy Mater. Sol. Cells 94, 114 (2010). 
2. J. Drechsel, B. Ma“nnig, F. Kozlowski, D. Gebeyehu, A. Werner, M. Koch, K. Leo, M. Pfeiffer, Thin Solid Films 451-452, 515 (2004).

3. S S. Braun, W.R. Salaneck, M. Fahlman, Adv. Mater. 21, 1450 (2009).

4. N.R. Armstrong, C. Carter, C. Donley, A. Simmonds, P. Lee, M. Brumbach, B. Kippelen,

B. Domercq, S. Yoo, Thin Solid Films 445, 342(2003).

5. E.L. Bruner, N. Koch, A.R. Span, S.L. Bernasek, A. Kahn, J. Schwartz, J. Am. Chem. Soc. 124, 3192 (2002).

6. B. Johnev, M. Vogel, K. Fostiropoulos, B. Mertesacker, M. Rusu, M.C. Lux -Steiner, A.

Weidinger, Thins Solid Films 488, 270 (2005).

7. X.-Y. Jiang, Z.-L. Zhang, J. Cao, W.-Q. Zhu, Solid-State Electronics 52, 952 (2008).

8. A. Godoy, L. Cattin, L. Toumi, F. R. Diaz, M.A. del Valle, G. M. Soto, B. Kouskoussa,

M. Morsli, K. Benchouk, A. Khelil, J. C. Bernède, Sol. Energy Mater. Solar Cells 94, 648 (2010).

9. J.C. Bernède, L. Cattin, M. Morsli, Y. Berredjem, Sol. Energy Mater. Solar Cells 92, 1508 (2008).

10. L. Cattin, F. Dahou, Y. Lare, M. Morsli, R. Tricot, K. Jondo, A.Khelil, K. Napo, J.C.

Bernède, J App. Phys. 105, 034507 (2009).

11. R.G. Gordon, Mat. Res. Soc. Symp. Proc., 426, 419 (1996).

12. J.C. Bernède, L. Cattin, M. Morsli, Y. Berredjem, Sol. Energy Mater. Solar Cell, 92, 1508 (2008).

13. P. Peumans, V. Bulovic, S.R. Forrest, Appl. Phys. Lett., 79, 2650 (2000).

14. R.F. Salzman, J. Xue, B.P. Rand, A. Alexander, M.E. Thompson, S.R. Forrest, Organic

Electronics, 6, 242 (2005).

15. Y. Berredjem, N. Karst, L. Cattin, A. Lkhdar-Toumi, A. Godoy, G. Soto, F. Diaz, M.A. del Valle, M. Morsli, A. Drici, A. Boulmok, A.H. Gheid, A. Khelil, J.C. Bernède, Dyes and Pigments 78, 148 (2008).

16. Y. Park, V. Choong, Y. Gao, B.R. Hsieh, C.W. Tang, Appl. Phys. Lett., 68, 2699 (1996).

17. C.-H. Wang, W.C.H. Choy, Sol. Energy Mater. Solar Cells 95, 904 (2011).

18. P. Peumans, S.R. Forrest, Appl. Phys. Lett. 79, 126 (2001).

19. J. Park, H. Min Kim, D. Wook Kim, J. Sun Choi, Appl. Phys. Lett., 97, 093301 (2010).

20. M.G. Helander, Z.B. Wang, J. Qiu, Z.H. Lu, Appl. Phys. Lett., 93, 193310 (2008).

21. Y. Shi, S.-C. Luo, W. Fang, K. Zhang, E.M. Ali, F.Y.C. Boey, J.Y. Yinng, J. Wang, H. -H

Yu, L.6J. Li, Organic Electronics, 9, 859 (2008).

22. C.S. Lee, J.X. Tang, Y.C. Zhou, S.T. Lee, Appl. Phys. Lett. 94, 113304. (2009).

23. C.V. Hoven, A. Garcia, G.C. Bazan, T. Q. Nguy en, Adv. Mater., 20, 3793 (2008).

24. B. Kouskoussa, M. Morsli, K. B enchouk, G. Louarn, L. Cattin, A. Khellil, J.C. Bernède, Physica Status Solidi (a) 206, 311 (2009).

25. F.J. Zhang, D.W. Zhao, Z.L. Zhuo, H. Wang, Z. Xu, Y.S. Wang, Sol. Energy Mater. Solar Cell 94, 2416-2421 (2010).

26. C.-H. Wang, W.C.H. Choy, Sol. Energy Mater. Solar Cells 95, 904 (2011).

27. M. Kröger, S. Hamwi, J. Meyer, T. Riedl, W. Kowalsky, A. Khan, Appl. Phys. Lett. 95, 123301 (2009).

28. X. Tong, B.E. Lassiter, S.R. Forrest, Org. Electronics 11, 705 (2010).

29. T. Matsushima, Y. Kinoshita, H. Murata, Appl. Phys. Lett. 91, 253504 (2007).

30. charge transfert

31. J. Mayer, A. Shu, A. Khan, Appl. Phys. Lett; 96, 133308 (2010).

32. M. Zhang, Irfan, H. Ding, Y. Gao, CC.W. Tang, Appl. Phys. Lett. 96, 183301 (2010).

33. I. Hancox, P. Sullivan, K.V. Chauchan, N. Beaumont, L.A. Rocheford, R.A. Hatton, T.S.

Jones, Organic Electronics 11, 2019 (2010) 
34. M.T. Greiner, M.G. Helander, Z.B. Wang, W.M. Tang, J. Qiu, Z.H. Lu, Appl. Phys. Lett. 96, 213302 (2010).

35. C.-W. Chu, S.-H. Li, C-W. Chen, V. Shrotriya, Y. Yang, Appl. Phys. Lett. 87, 193508 (2005).

36. H. You, Y. Dai, Z. Zhang, D. Ma, J. Appl. Phys. 101, 026105 (2007).

37. T. Hori, T. Shibata, V. Kittichungchit, H. Moritou, J. Sakai, H. Kubo, A. Fujii, M. Ozaki, Thin Sold Films 518, 522 (2009).

38. G. Garcia-Belomonte, J. Bisquert, Appl. Phys. Lett., 96 (2010) 113301.

39. A.K. Thakur, G. Wantz, G. Garcia-Belomonte, J. Bisquert, L. Hirsh, Sol. Energy Mater.

Solar Cells, 95 (2011) 2131 -2135.

40. R.C.I.MacKenzie, T. Kirchartz, G.F.H. Dibb, J. Nelson, Journ. Phys. Chem. C 115 (2011) 9806-9813.

41. Y. Kinoshita, T. Hasobe, H. Murata, Appl. Phys. Lett. 91 (2007) 083518.

42. D. Fujishima, H. Kanno, T. Kinoshita, E. Maruyama, M. Tanaka, M. Shirakawa, K. Shibate, Sol. Energy Mater. Solar Cells, 93 (2009) 1029 -1032. 


\section{Scheme}

Scheme 1: Chemical structure of the electron donors used.

\section{Figures}

Figure 1: Typical J-V characteristics of $\mathrm{ITO} / \mathrm{ED} / \mathrm{C}_{60} / \mathrm{BCP} / \mathrm{Al}$ structure, with $\mathrm{ED}=$ $\operatorname{CuPc}(\bullet)$,pentacene ( ) and DBP ( ).

Figure 2: Typical J-V characteristics of $\mathrm{TCO} / \mathrm{Au}(0.5 \mathrm{~nm}) / \mathrm{ED} / \mathrm{C}_{60} / \mathrm{BCP} / \mathrm{Al}$ structure, with $\mathrm{ED}$ $=\operatorname{CuPc}(\bullet)$,pentacene $($ ) and DBP $(\quad)$.

Figure 3: Typical J-V characteristics of $\mathrm{TCO} / \mathrm{MoO}_{3}(0.5 \mathrm{~nm}) / \mathrm{ED} / \mathrm{C}_{60} / \mathrm{BCP} / \mathrm{Al}$ structure, with $\mathrm{ED}=\operatorname{CuPc}(\bullet)$, pentacene ()$, \operatorname{DBP}(\quad)$ and T3PM $(+)$.

Figure 4: Surface visualization of a T3PM film (a) and of a DBP (b) film deposited onto a $\mathrm{MoO}_{3} / \mathrm{ITO} /$ bare glass substrate.

\section{Tables}

Table 1: Highest occupied molecular orbital (HOMO) and lower unoccupied molecular orbital (LUMO).

Table 2: Different bibliographic values of Valence Band (VB), Conduction Band (CB) and Work Function $\left(\Phi_{\mathrm{M}}\right)$ of $\mathrm{MoO}_{3}$. 

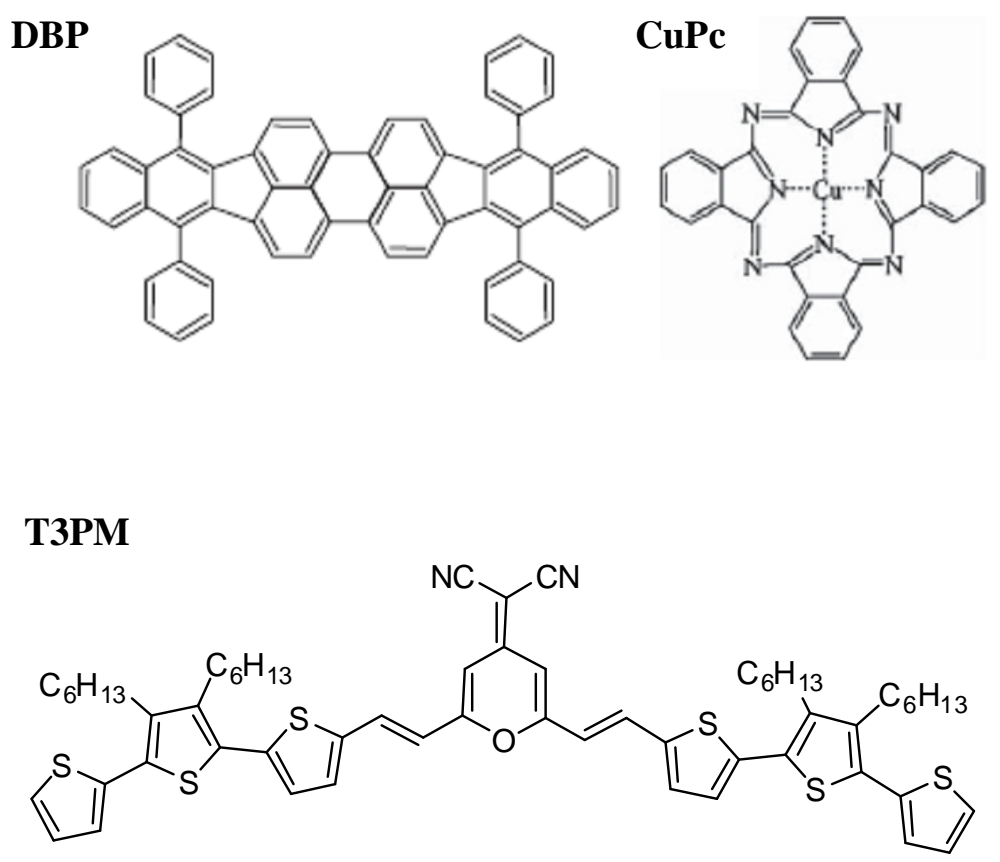

Pentacene

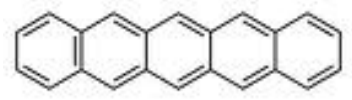

Scheme 1: 


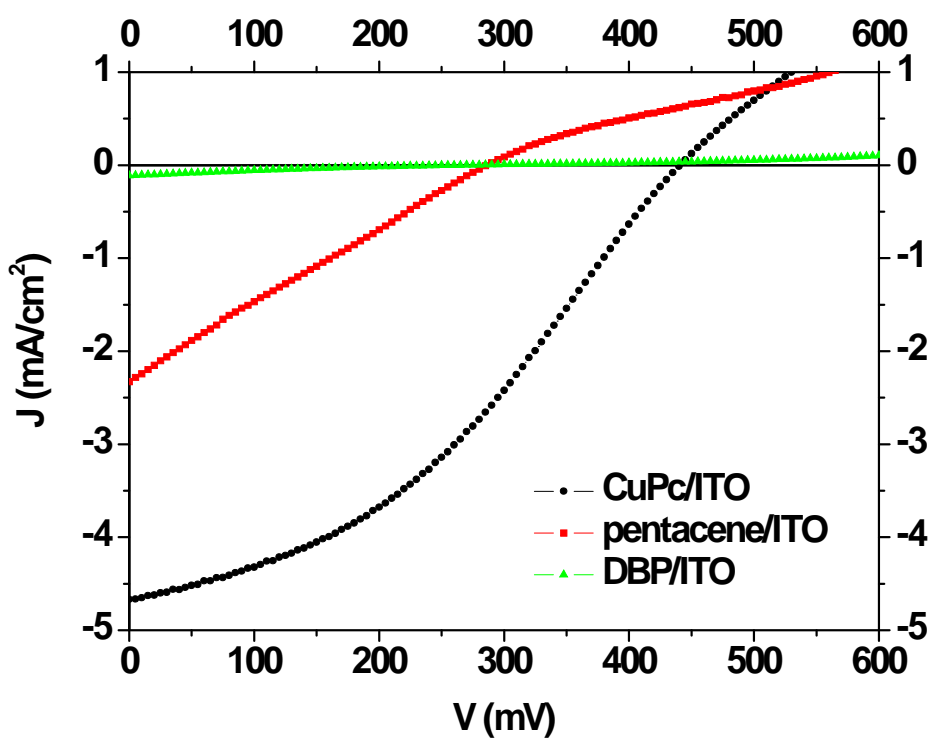

Figure 1

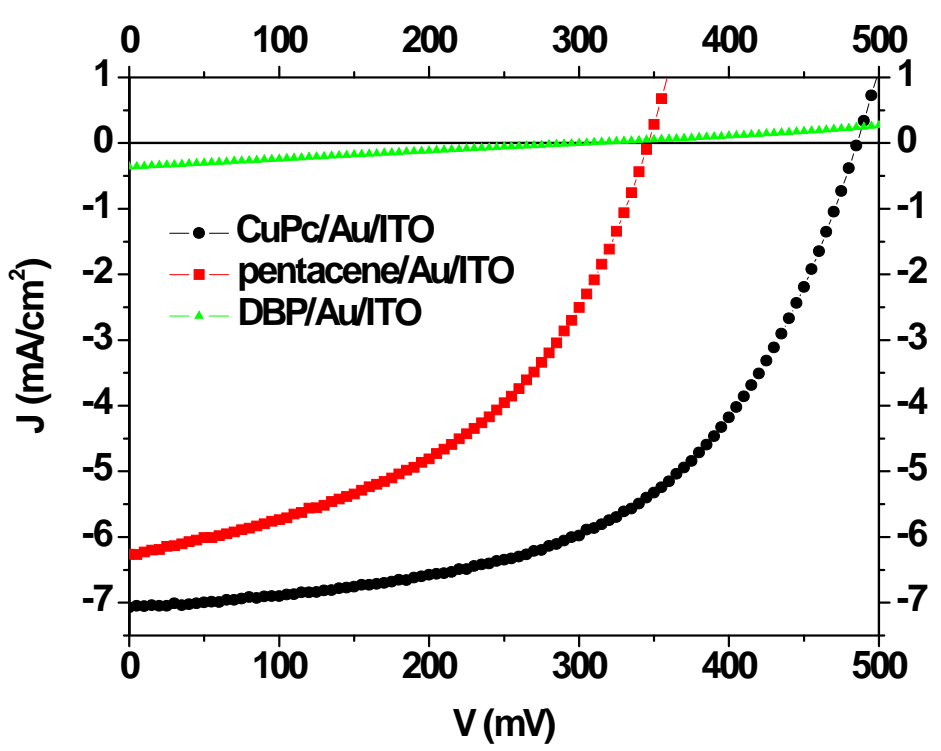

Figure 2 


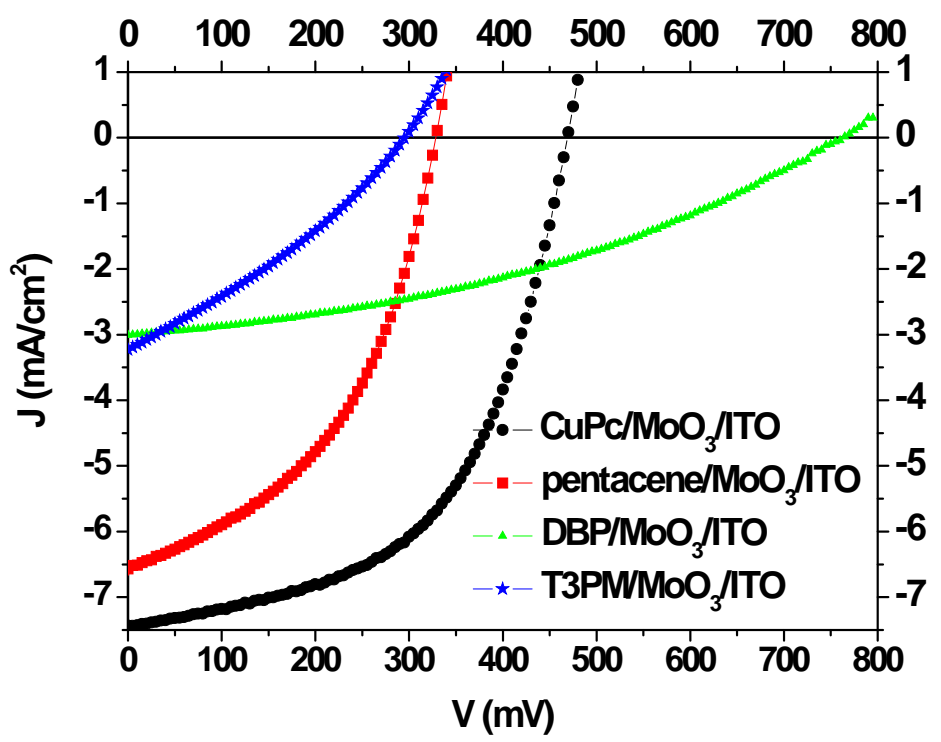

Figure 3 

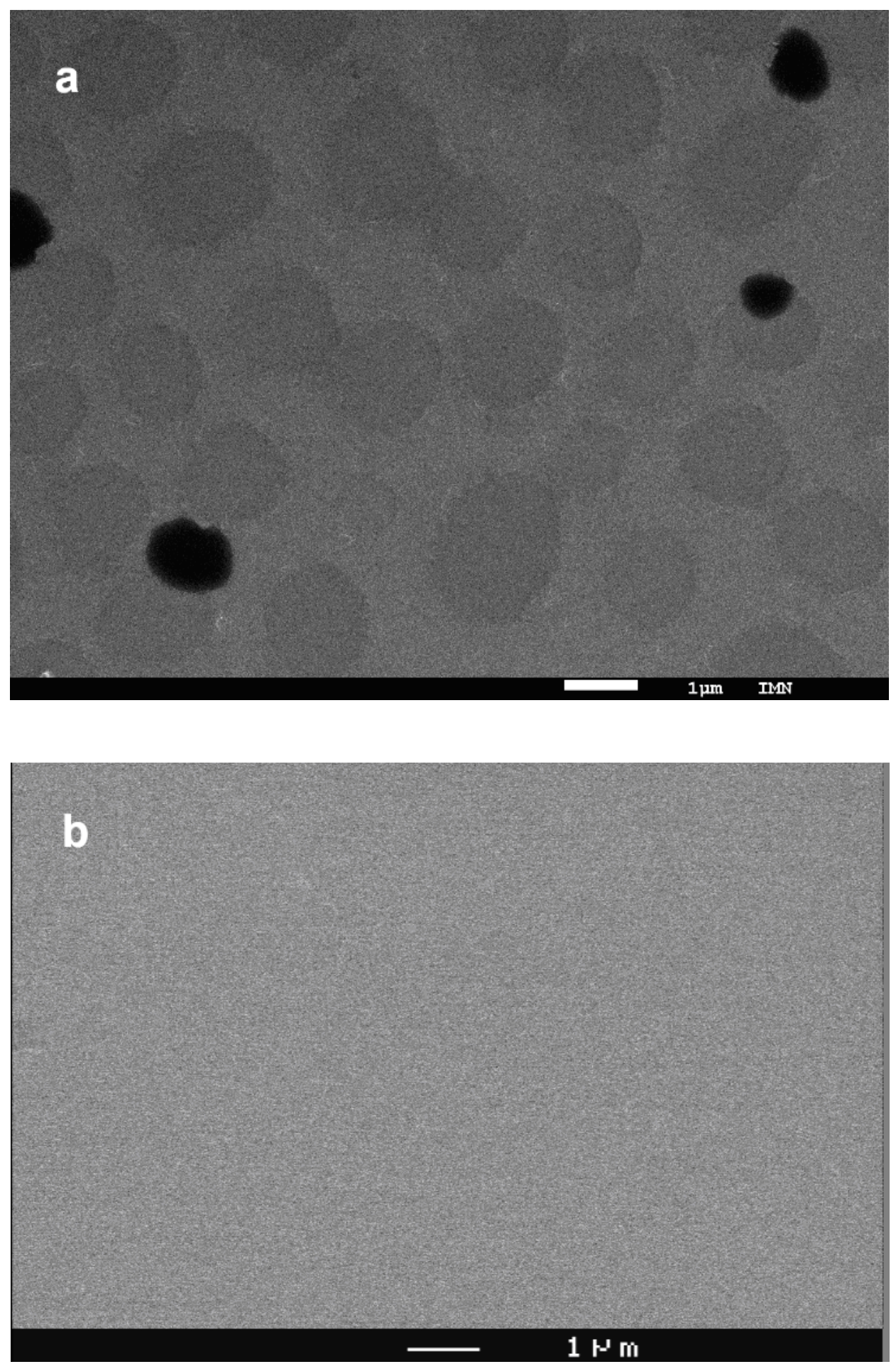

Figure 4 


\begin{tabular}{|c|c|c|}
\hline Electron donnor & HOMO $(\mathrm{eV})$ & LUMO $(\mathrm{eV})$ \\
\hline Pentacene [41] & 5 & 2 \\
\hline CuPc [41] & 5.2 & 3.5 \\
\hline DBP [42] & 5.5 & 3.5 \\
\hline T3PM & 5.7 & 3,7 \\
\hline
\end{tabular}

Table 1

\begin{tabular}{|c|c|c|c|c|}
\hline Reference & VB $(\mathrm{eV})$ & CB $(\mathrm{eV})$ & $\Phi_{\mathrm{M}}$ & Comment \\
\hline$[35]$ & 5.3 & 2.3 & & \\
\hline$[36]$ & $5.3-5.4$ & 2.3 & $5.3-5.5$ & \\
\hline$[37]$ & 5.3 & 1.8 & 5.3 & Type n \\
\hline$[27]$ & 9.7 & 6.7 & 6.86 & Type n, clean \\
\hline$[31]$ & 9.7 & 6.7 & 6.86 & Type n, contaminated \\
\hline$[32]$ & 8.6 & 5.5 & 5.7 & Type n, clean \\
& & & 6.8 & Type n, contaminated \\
\hline$[34]$ & & & 5.2 & $\mathrm{MoO}_{3}$ \\
& & & 5.8 & $\mathrm{Mo}_{2.5}$ \\
\hline
\end{tabular}

Table 2 